\title{
Causal Factors Analysis Unsynchronized Occupation with The Competency during The Study
}

\author{
Andika Bagus Nur Rahma Putra ${ }^{1}$, Syarif Suhartadi ${ }^{2}$, Imam Muda Nauri ${ }^{3}$, Windra Irdianto ${ }^{4}$, Erwin \\ Komara Mindarta ${ }^{5}$ \\ \{andika.bagus.ft@um.ac.id ${ }^{1}$, syarif.ft@um.ac.id ${ }^{2}$, imuna oto@yahoo.co.id ${ }^{3}$, \\ windra.irdianto.ft@um.ac.id ${ }^{4}$,erwin.komara.ft@um.ac.id $\left.{ }^{5}\right\}$ \\ 1,2,3,4,5 Department of Engineering, Universitas Negeri Malang, Malang, Indonesia
}

\begin{abstract}
The demand for qualified human resources is needed to compete in the free market era. Unfortunately, Indonesian human resources are still considered low compared to the international professional and as a result, industry finds it difficult to recruit qualified and proficient human resource in a prompt time. In the level of undergraduate, the graduates who possess skill and ability are lacking. It is because the graduates mostly apply for a job which is not in line with their study program. This study aims at (1) describing a graduates occupation and job profile, and (2) identifying causal factors of the unsynchronized professional occupation of graduates with the preceding Major during their study in the last three years. A number of at least $10 \%$ of the entire subjects which is recorded in Alumnus Book Record of Faculty of Engineering and who are able to be contacted were taken as a sample. This study used semi-structured filling questionnaire instrument which was collected through electronic media such as phone calls, WhatsApp, FaceBook, and Instagram. This study showed that (1) the graduates who decide to become an educator (teacher/lecturer) is $36 \%$. A number of $21 \%$ graduates decide to work in industry or commerce. A number of $17 \%$ graduates decide to work within government agency or institution and the rest of $26 \%$ decide to start up their business or become an entrepreneur and (2) there are two major factors of causal factors of the unsynchronized occupation of graduates with the areas of expertise during the study in university. The factors are internal (the deficiency in mastering materials and competencies during the study in university, the low motivation to become an educator, and the low self-concept within the individual) and external (the deficiency of educational facility and infrastructure during the study in university, the availability of synchronized job in their native land, and the limited connection of the graduates).
\end{abstract}

Keywords: unsynchronized occupation, vocational college graduates, areas of expertise, graduates occupation.

\section{Introduction}

Recently, the people's demand regarding qualified education standard is getting higher (Barthes and Lange, 2018). It is shown by the function of education which has become a social life that is strong and authoritative. The demand for qualified and proficient human resources is highly required due to the increasing competition in the free market era (Nahar, Subadriyah and Sofwan, 2017). One important and paramount attempt taken by the government to manufacture and encourage qualified and proficient human resources is through education. Unfortunately, Indonesian human resources are still considered low compared to the international professional and as a result, industry finds it difficult to recruit qualified and proficient human resource in a prompt time.

The upcoming investors, both foreign and local investors, which bring brand-new technologies find it difficult to recruit proficient new employees in Indonesia (Sadewo 
et al., 2018). It is caused by the limited number of qualified and proficient human resources who are ready to be employed. In fact, the number of Indonesian graduates is considered enormous. The enormous number of graduates mostly do not possess expected and relatable skills in technology and industry areas (Habibi et al., 2018). The graduates are dominated by Humanities and Social Sciences field who do not meet the criteria the market demand. The graduate's supply has been enormous. However, the supply of graduates possessing skill are limited (Campbell, Adamuti-Trache, and Bista, 2018). In the end, it impacts the low and high level of human resource pyramid which undergoes paradox or commonly called as an anomaly. In addition, it potentially harms the national development, both in recent development and in the upcoming development.

At the undergraduate level, there is a deficiency of skills and expertise of university graduates (Officer, 2017). These deficiencies occur at the medium and high levels. Workers with medium and high skills are much needed in line with the modernization of the Indonesian economy, but in fact, the number is insignificant. Meanwhile, at the bottom level, the number of the uneducated and unskilled worker is innumerable and significant (Kowalewski, 2017). If a government institution or private company opens vacancies openly for lower-class workers, then the applicants who come to register and submit themselves to be a future employee is abundant. This indicates that the number of unskilled labor is very large and significant. Minister of Manpower, Hanif Dhakiri said that the growth of the new workforce averaged about 2 million people. Of these, about $37 \%$ of the workforce is working in accordance with the education majors. This means that as many as $63 \%$ of Indonesians work out of line with their majors (areas of expertise).

As a matter of this fact, the government has launched a vocational education acceleration which aims at preparing students to be productive and able to work independently (Education and Harcourt, 2018). This is done in order to fulfill job vacancies in business and industry activities as middle-level workforce and in accordance with the competence within the course of expertise chosen by the students. In addition, vocational education also equips learners to be able to determine a career, become a tenacious and persistent individual in competing, acclimate to the work environment and develop a professional attitude in the interested field of expertise. (van de Werfhorst, 2017).

In addition, vocational education that plays a role to equip learners with science, technology, and arts should be able to develop themselves in the future either independently or through higher education level (Ridzwan et al., 2017). However, the current vital problem is the absorption of university graduates by business and industry activities which cause limited employment. These conditions tend to lead to open unemployment (Hippach-Schneider et al., 2017). Various problems related to quality, relevance and educational competitiveness faced by college graduates are required to be immediately resolved through alternative solution and approach in order to achieve the vision and mission of vocational education. For example, for example, a graduate student in economics is in fact not always an economist, law graduates are not always legal practitioners. In addition, there are still many fresh graduates decided to work in a field that is completely different from the previous course majors. Other examples such as graduates from the faculty of agriculture work in banks, graduates of the faculty of geography entrepreneurship in the field of printing. It makes the growth of interest in the public interest in the economic needs become dominant (Glavin and Young, 2017). 
Hence, most of the people start thinking that every single occupation should be able to earn beneficial income in the form of money although at the end the occupation does not in line with the expertise and skill they possess. (Battaglio and Gelgec, 2016). On the other case, some of the graduates decide to apply for a job which is not in line with the expertise and skill as a stepping stone to only obtain an experience in professional work. Indeed, there will be a diverse opinion regarding professional matter since every individual will have their own perspective and consideration.

\section{Method}

This present study was conducted by employing the qualitative method and survey design. The qualitative method of this study was conducted by tracking Universitas Negeri Malang graduates. This method was selected in accordance with the aim of this study: describing graduates profile of Universitas Negeri Malang in performing their professional occupation, and identifying causal factors of the unsynchronized professional occupation of graduates with the preceding Major during their study. The subject of this study is the entire graduates of Faculty of Engineering Universitas Negeri Malang (UM) in the last three years. Then, a number of at least $10 \%$ of the entire subjects which is recorded in Alumnus Book Record of Faculty of Engineering and who are able to be contacted were taken as a sample. This study used semistructured filling questionnaire instrument which was collected through electronic media such as phone calls, WhatsApp, FaceBook, and Instagram. Then, the data obtained were analyzed using percentage descriptive statistic. While qualitative data analysis was done to analyze study program curriculum documents, content analysis. And, the data analysis on qualitative method was done descriptively.

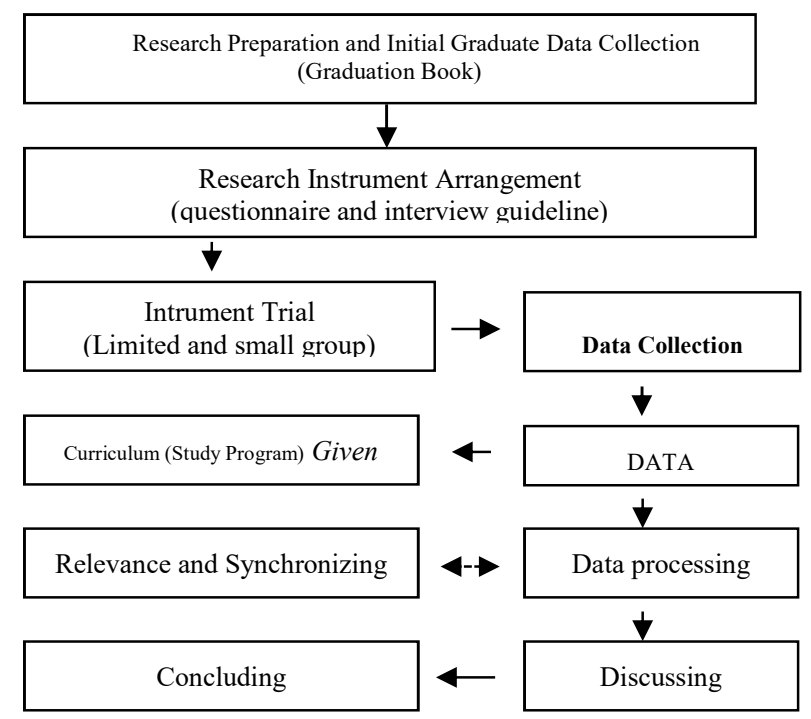

Fig. 1. Research Design Plan. 


\section{Results}

The profile of graduates presented includes a description of the work of the graduates recently. The profile of graduates is obtained from survey and observation. Description of the causal factors of unsynchronized occupation with the study program during the study was obtained through interviews with the group of graduates who undergo unsynchronized occupation with the study program during the study.

In the graduate's profiles study, it is grouped into four areas of work. The four areas of work include the types of work of educators (teachers/lecturers), industry/commerce, employees/governance, and entrepreneur. The grouping is based on the priority of the four largest jobs from the survey results of graduates of teacher's training program. Table 1 presents the percentage of each occupation type.

Table 1. The percentage of each occupation type.

\begin{tabular}{llc}
\hline No. & \multicolumn{1}{c}{ Field of work } & Percentage \\
\hline 1 & Educator (teachers/lecturers) & $36 \%$ \\
\hline 2 & Industry/Company & $21 \%$ \\
\hline 3 & Government Institution & $17 \%$ \\
\hline 4 & Entrepreneur & $26 \%$ \\
\hline
\end{tabular}

In Table 1, it can be expressed that the percentage in each work field have different values. The table shows that graduates who decide to become an educator (teacher/lecturer) are $36 \%$. A number of $21 \%$ graduates decide to work in industry or commerce. A number of $17 \%$ graduates decide to work within government agency or institution and the rest of $26 \%$ decide to start up their business or become an entrepreneur.

Data description regarding causal factors of unsynchronized work with the areas of expertise during the study were generated from the distributed questionnaire and interview with the subject. The questionnaires were classified and processed in the tabulation of data. The tabulation process of the data generated a percentage from each question item. The percentage generated is presented in Table 2 below.

Table 2. Percentage from each question item.

\begin{tabular}{llcc}
\hline \multirow{2}{*}{ No. } & Topics/Questions & \multicolumn{2}{c}{ Percentage } \\
\cline { 3 - 4 } & & Yes & No \\
\hline 1 & Understanding all the competencies during the study & $75 \%$ & $25 \%$ \\
\hline 2 & Capability in completing all the issue within the study & $40 \%$ & $60 \%$ \\
\hline 3 & $\begin{array}{l}\text { Possessing supporting skill related to competencies during the } \\
\text { study }\end{array}$ & $45 \%$ & $65 \%$ \\
\hline 4 & Mastering various learning models & $80 \%$ & $20 \%$ \\
\hline 5 & Able to teach innovatively and interactively & $40 \%$ & $60 \%$ \\
\hline 6 & Able to manage class during learning process & $40 \%$ & $60 \%$ \\
\hline 7 & Knowing actively all information related to job vacancy & $35 \%$ & $65 \%$ \\
\hline 8 & Understanding self-capability and potency & $70 \%$ & $30 \%$ \\
\hline 9 & Understanding the job opportunity & $50 \%$ & $50 \%$ \\
\hline 10 & Unabridged instructional media & $45 \%$ & $55 \%$ \\
\hline
\end{tabular}




\begin{tabular}{llcc}
\hline No. & \multicolumn{1}{c}{ Topics/Questions } & \multicolumn{2}{c}{ Percentage } \\
\cline { 3 - 4 } & & Yes & No \\
\hline 11 & Able to utilize facility and infrastructure for learning process & $85 \%$ & $15 \%$ \\
\hline 12 & Modernization of facility and infrastructure during study & $40 \%$ & $60 \%$ \\
\hline 13 & The diversity of job field in his or her native land & $40 \%$ & $60 \%$ \\
\hline 14 & $\begin{array}{l}\text { Job vacancy in his or her native land is in accordance with the } \\
\text { competency during the study }\end{array}$ & $35 \%$ & $65 \%$ \\
\hline 15 & $\begin{array}{l}\text { The availability of job vacancy which is in accordance with the } \\
\text { competency during the study }\end{array}$ & $45 \%$ & $55 \%$ \\
\hline 16 & $\begin{array}{l}\text { Friends or classmates who have a job which is in accordance with } \\
\text { the competency during study }\end{array}$ & $30 \%$ & $70 \%$ \\
\hline 17 & Relationship with friend who has worked & $45 \%$ & $55 \%$ \\
\hline 18 & Having high social ability & $75 \%$ & $25 \%$ \\
\hline
\end{tabular}

According to Table 2, it can be explained that the percentage of students who answered yes on the topic/question about understanding all the competencies during the study is $75 \%$ and students who answered no is $25 \%$. The percentage of students who answered yes on the topic/question about capability in completing all the issue within lecturer is $40 \%$ and students who answered no is $60 \%$. The percentage of students who answered yes on the topic/question about supporting skill related to competencies during the study is $45 \%$ and students who answered no is $65 \%$. The percentage of students who answered yes on the topic/question about mastering various learning models is $80 \%$ and students who answered no is $20 \%$. The percentage of students who answered yes on the topic/question about the ability to teach innovatively and interactively is $40 \%$ and students who answered no is $60 \%$. The percentage of students who answered yes on the topic/question about the ability to manage class during learning process is $40 \%$ and students who answered no is $60 \%$.

The percentage of students who answered yes on the topic/question about knowing actively all information related to job vacancy is $35 \%$ and students who answered no is $65 \%$. The percentage of students who answered yes on the topic/question about understanding self-capability and potency is $70 \%$ and students who answered no is $30 \%$. The percentage of students who answered yes on the topic/question about instructional media employed in learning is $45 \% \%$ and students who answered no is $55 \%$. The percentage of students who answered yes on the topic/question about supporting facility and infrastructure for learning process is $85 \%$ and students who answered no is $15 \%$. The percentage of students who answered yes on the topic/question about the modernization of facility and infrastructure during the study is $40 \%$ and students who answered no is $60 \%$. The percentage of students who answered yes on the topic/question about the diversity of job field in his or her native land is $40 \%$ and students who answered no is $60 \%$.

The percentage of students who answered yes on the topic/question about job vacancy in his or her native land is in accordance with the competency during the study is $35 \%$ and students who answered no is $65 \%$. The percentage of students who answered yes on the topic/question about the availability of job vacancy which is in accordance with the competency during the study is $45 \%$ and students who answered no is $55 \%$. The percentage of students who answered yes on the topic/question about friends or classmates who have a job which is in accordance with the competency during the study is $30 \%$ and students who answered no is $70 \%$. The percentage of 
students who answered yes on the topic/question about the relationship with a friend who has worked is $45 \%$ and students who answered no is $55 \%$. The percentage of students who answered yes on the topic/question regarding high social ability is $75 \%$ and students who answered no is $25 \%$.

\section{Discussion}

This study intends to uncover the major causal factors of the unsynchronized occupation of graduates with the areas of expertise during the study in university. The results of this study indicate that there are two major factors of causal factors of the unsynchronized occupation of graduates with the areas of expertise during the study in university. The factors are classified into two; internal factor and external factor.

\subsection{Internal Factor}

The internal factor causing unsynchronized occupation of graduates with the areas of expertise during the study in university originated from the graduates themselves. One of the paramount factors is the condition where the graduates did not master the entire competencies during their study in university. The moment the graduates did not master the entire competencies during their study in university, it hampers the recruitment process. The graduates tend to not optimally do the test (Indiana, Champe, and Pimpleton-Gray, 2017). Directly, the graduates do not possess supporting skills which are related with the competencies they deem to be acquired during their study in university. Therefore, the graduates are difficult to develop their capability in accordance with the expertise they chose back then. To sum up, all materials obtained during the study in university take an important role in developing and sharpening the competency of the students which is beneficial in finding a relatable job based on their area or of expertise.

In addition to the aforementioned explanation, this study also reveals internal factor which causes unsynchronized occupation of graduates with the areas of expertise during the study in university, the namely low motivation of becoming a teacher. The passion for becoming a teacher is related to how the devotion of teacher in teaching which it will eventually influence the students' ability development.(Simić, Purić and Stančić, 2018). If, as a teacher, they do not devote him or herself in teaching, the role as a teacher will not be effective. Some studies have revealed that most teachers decide to teach is not because they really want to devote him or herself in teaching, yet, they were forced by other conditions other than passion. Such situation provides no opportunity to develop students (prospective teacher/lecturer) knowledge and competency and at the end, they do not devote to completely teach (Yeşil and Demiröz, 2017). Motivation is the most important factor which influences the readiness of students to become a professional teacher. The students' readiness is reflected in the competency they possessed. During teaching practicum in a school, students likely had deficient knowledge and competency as a teacher since they do not passionately devote him or herself as a teacher. (Simić, Purić and Stančić, 2018). Incommensurate income with the teaching hours in school as a teacher becomes the one and major factor why students do not want to devote him or herself as a teacher. In addition, several studies discover that in fact, teaching in private school does not offer a promising income rather than teaching in state-owned school. Additionally, this factor also constructs the negative attitude of students as a prospective teacher (Sharma, 2017). 
The interview result also revealed that weak self-concept among graduates of teaching study program is the other internal factors which cause unsynchronized occupation of graduates with the areas of expertise during the study in university. It was delivered by most of the graduates during the interview process. Essentially, selfconcept is a set of mental control instruments and thereby affects one's thinking ability (Afgani, Suryadi, and Dahlan, 2018). A person who has a positive self-concept will be an individual who is able to view him or herself positively, dare to try and take risks, always think optimistically, feel confident, and enthusiastically set the direction and purpose of life. Given the importance of self-concept to a person then the formation of self-concept is an integral part of the educational process. In addition, the meaning of self-concept consists of three forms. First, body image is an awareness of individual regarding body and how one sees and perceives it. Second, the idea of self which explains how the ideal visions and expectations regarding him or herself. The third is the social self, that is how others see themselves. In carrying out the role of educators, in this case, is the teacher, in the classroom learning process often encounters various problems in dealing with difficult learning situation and the behaviour of the learners which is difficult to control. (Cooper, Higgins and Beckmann, 2017). This condition can be caused by the lack of knowledge and experience of educators in addressing the learning situation and psychological understanding of students. In dealing with difficult learning situation, an educator must have a good emotional awareness that is a positive self-concept (Nurul Aina, 2017). This positive self-concept is very important because it is impossible for the educators to be able to control students' emotion and learning situation if they are not able to control their own emotion. Emotional control can be done if an educator possesses a positive self-concept. This positive self-concept is a self-concept that is always oriented to positive thinking, seeks opportunities in every difficulty, and seeks answers to every problem (Afgani, Suryadi, and Dahlan, 2018). The personality of an educator who has a positive self-concept always appears calmly, confidently, resiliently, patiently, and confidently in the front of learners. In addition, they are able to control and manage any learning situation.

According to the aforementioned explanation, it can be wrapped up that factor causing unsynchronized occupation of graduates with the areas of expertise during the study in university is the internal factors from the individual. The factors are comprising of the deficiency in mastering materials and competencies during the study in university, the low motivation to become an educator and the low self-concept within the individual.

\subsection{External Factor}

The results of this study also reveal that external factor contributes to the factor causing unsynchronized occupation of graduates with the areas of expertise during the study in university. The results of interview and survey on graduates of teaching program department explain that facility and infrastructure in university did not completely support the learning process. The graduates explained that the supporting instructional media and learning facility and infrastructure was lacking. It indeed influences the learning process and the development of the individual during the study in university (Sulaiman, 2017). Supporting instructional media and learning facility and infrastructure play an important role in generating a successful learning process. In addition, these facilities become the measurement of the quality of educational 
institution since it reflects the improvement and development of science and technology within the educational institution.

On the other hand, these facility and infrastructure take a role as one part of the input, while input is one of the subsystems. Facility and infrastructure should be seriously taken into account by the institution to support learners' skill development in order to be able to compete in work circumstance and adapt with the rapid development of technology (Sulaiman, 2017). Facility and infrastructure are paramount elements which should be prepared thoroughly and continuously to be able to ensure better learning process. Educational facility and infrastructure directly correlate with the learning process. The existence of unabridged educational facility and infrastructure motivate individual establishment of active attitude and behavior in the learning process. Through the attempt of teaching and training, education takes a role as a mean of cultural inheritance and as a mean of patriotic citizenship formation. Furthermore, in the long-run, education should be able to prepare the individual to become a qualified employee.

Facilities and infrastructure are factors that support the success of educational programs within the learning process. The quality of facilities and infrastructure is varied. This lack of educational facilities and infrastructure has an impact on the low level of educational output because, in this era of globalization technology, the transformation of education is required that requires advanced and brand-new facilities and infrastructure in order to compete with global markets. The lack of this facility only offers the learners to theoretically learn without real practice and at the end, learners will only learn in their imagination which does not reflect the reality (Nurul Aina, 2017).

Another result of this study explained that the causal factor of unsynchronized occupation with study program during the study in university is the unavailability of job vacancy related to their study program in their native land. It becomes an urgent issue for most of the graduates. Some studies reveal that several areas have a limited category and variety of job and occupation. This phenomenon forces the graduates to apply for a job or occupation which is not in line with their study program due to the limited variety. In addition, the job and occupation are not in accordance with their competencies (Battaglio and Gelgec, 2016). Also, it is presumably because the graduates did not have a relationship or did not attempt to expand their relation which is beneficial for their future career.

Establishing a connection with colleagues is an important component in order to ensure the synchronized job with the competency of the graduates. It is important to establish a connection since by having an expanded connection, the graduates will obtain a varied information of job and career which is in line with their study program and competency(Nahar, Subadriyah and Sofwan, 2017). In addition, by having a connection which encourages a communication, it also offers the graduates a better experience sharing. Generally and essentially, every single individual aim at achieving a successful life in terms of financial. If the individual aims at achieving successful life financially and obtaining a decent job which is in line with the competency he or she possessed, the individual indeed needs a connection with right people. This connection allows the individual to meet people who can help the individual to obtain a decent job.

According to the aforementioned explanation, it can be wrapped up that factor causing unsynchronized occupation of graduates with the areas of expertise during the study in university also comes from the internal factors from the individual. The factors 
are comprising of the deficiency of educational facility and infrastructure during the study in university, the availability of synchronized job in their native land, and the limited connection of the graduates

\section{Conclusion}

Pursuant to the results and discussion of this present study above, it can be sum up that first, the graduates who decide to become an educator (teacher/lecturer) is $36 \%$. A number of $21 \%$ graduates decide to work in industry or commerce. A number of $17 \%$ graduates decide to work within government agency or institution and the rest of $26 \%$ decide to start up their business or become an entrepreneur. Second, there are two major factors of causal factors of the unsynchronized occupation of graduates with the areas of expertise during the study in university. The factors are classified into two; internal factor and external factor. The internal factors are comprising of the deficiency in mastering materials and competencies during the study in university, the low motivation to become an educator and the low self-concept within the individual. The external factors are comprising of the deficiency of educational facility and infrastructure during the study in university, the availability of synchronized job in their native land, and the limited connection of the graduates.

\section{References}

[1] Afgani, M. W., Suryadi, D. and Dahlan, J. A. (2018) 'Developing self-concept instrument for pre-service mathematics teachers Developing self-concept instrument for pre-service mathematics teachers', Journal of Physics: Conference Series, 948, pp. 1-7.

[2] Barthes, A. and Lange, J. M. (2018) 'Researchers' positions and construction of curricula of education for sustainable development in France', Journal of Curriculum Studies. Routledge, 50(1), pp. 96-112. doi: 10.1080/00220272.2017.1347716.

[3] Battaglio, R. P. and Gelgec, S. (2016) 'Exploring the structure and meaning of public service motivation in the Turkish public sector: a test of the mediating effects of job characteristics', Public Management Review. Routledge, 1(1), pp. 1-19. doi: 10.1080/14719037.2016.1235723.

[4] Campbell, T. A., Adamuti-Trache, M. and Bista, K. (2018) 'Chinese International Students 'Perceptions of their Language Issues in U. S . Universities : A Comparative Study', Journal of International Students, 6(1), pp. 409-430. doi: 10.5281/zenodo.1134319.

[5] Cooper, D., Higgins, S. and Beckmann, N. (2017) 'Online instructional videos as a complementary method of teaching practical rehabilitation skills for groups and individuals', Journal of Education Technology Systems, 45(4), pp. 546-560. doi: 10.1063/1.2756072.

[6] Education, T. and Harcourt, P. (2018) 'Strategies for Improving Female Students ' Enrolment in Technical and Vocational Education Programmes Through Public', International Journal of Advanced Academic Research, 4(1), pp. 1-13.

[7] Glavin, P. and Young, M. (2017) 'Insecure People in Insecure Places: The Influence of Regional Unemployment on Workers' Reactions to the Threat of Job Loss', Journal of Health and Social Behavior, 1(1), pp. 1-20. doi: $10.1177 / 0022146517696148$. 
[8] Habibi, A. et al. (2018) 'Building an online community: Student teachers' perceptions on the advantages of using social networking services in a teacher education program', Turkish Online Journal of Distance Education, 19(1), pp. 46-61. doi: 10.17718/tojde.382663.

[9] Hippach-Schneider, U. et al. (2017) 'The underestimated relevance and value of vocational education in tertiary education-making the invisible visible', Journal of Vocational Education and Training. Routledge, 69(1), pp. 28-46. doi: 10.1080/13636820.2017.1281342.

[10] Indiana, J. A. C., Champe, J. and Pimpleton-Gray, A. (2017) 'A Career Exploration and Decision-Making Psychoeducational Group: Supporting Undergraduate Students and Training Graduate Students', Journal of Counseling in Illinois (JCI), 4(1), pp. 8-23.

[11] Kowalewski, T. (2017) 'Value Of Work In Relation To Cyber Threats In The Development Of New Competencies', Pol. J. Appl. Sci., 3, pp. 91-96.

[12] Nahar, A., Subadriyah and Sofwan, A. (2017) 'The Analysis of Human Resources Policies and Regional Financial Accounting System on Regional Government Financial Statements' Quality', sriwijaya international journal of dynamic economics and business, 1(4), pp. 387-404.

[13] Nurul Aina, Z. (2017) 'The effects of inclusive education on self-concept of students with special educational needs', Journal of ICSAR, 1(1), pp. 25-31. Available at: journal2.um.ac.id/index.php/icsar/article/download/359/247.

[14] Officer, D. R. (2017) 'Book Review', The Innovation Journal: The Public Sector Innovation Journal, 22(3), pp. 1-4. doi: 10.1080/00231940.1992.11758204.

[15] Ridzwan, C. R. et al. (2017) 'Skills and Knowledge Competency of Technical and Vocational Education and Training Graduate', Asian Social Science, 13(4), pp. 69-77. doi: 10.5539/ass.v13n4p69.

[16] Sadewo, F. S. et al. (2018) 'Empowering local potential resources: strategies and challenges of vocational high school in East Java Empowering local potential resources : strategies and challenges of vocational high school in East Java', Journal of Physics: Conference Series, 953, pp. 1-6.

[17] Sharma, S. (2017) 'Prospective teachers', International Education \& Research Journal [IERJ], 3(8), pp. 156-157. doi: 10.1080/02619760802208429.

[18] Simić, N., Purić, D. and Stančić, M. (2018) 'Motivation for the teaching profession: Assessing psychometric properties and factorial validity of the Orientation for Teaching Survey on in-service teachers *', Psihologija journal, 1(1), pp. 1-23.

[19] Sulaiman (2017) 'Classroom Management: Learners' Motivation and Organize The Learning Environment Of Pai', International Journal of Islamic Studies, 4(2), pp. 273-290.

[20] van de Werfhorst, H. G. (2017) 'Vocational and Academic Education and Political Engagement: The Importance of the Educational Institutional Structure', Comparative Education Review, 61(1), pp. 111-140. doi: 10.1086/689613.

[21] Yeşil, Ş. and Demiröz, H. (2017) 'An Exploration of English Language Teachers' Perceptions of Culture Teaching and Its Effects on Students' Motivation', International Journal of Progressive Education, 13(1), pp. 79-95. 
